\title{
ANALISIS PENAWARAN TENAGA KERJA WANITA MEMILIKI BALITA DI PERDESAAN SUMATERA BARAT
}

\author{
ANALYSIS SUPPLY OF WOMEN LABOR WHO HAVE TODDLER AT RURAL \\ AREA IN WEST SUMATRA
}

\author{
Sri Maryati, Elfindri, Nasri Bachtiar \\ Fakultas Ekonomi Universitas Andalas, srie_jayamahe@yahoo.co.id \\ Fakultas Ekonomi Universitas Andalas, elfindribana@gmail.com \\ Fakultas Ekonomi Universitas Andalas, nas_ri2002@yahoo.com.
}

\begin{abstract}
Abstrak
Penelitian ini bertujuan untuk menemukan faktor yang mempengaruhi penawaran tenaga kerja wanita yang memiliki Balita di Sumatera Barat. Keputusan memasuki pasar kerja yang harus diambil oleh wanita pada umumnya dan wanita yang memiliki balita khususnya sangatlah kompleks, diantaranya tergantung pada latar belakang individu dan pengaruh keluarga serta lingkungan. Variabel yang dikaji dalam studi ini adalah karakteristik individu, karakteristik keluarga dan karakteristik pekerjaan suami, dengan objek penelitian wanita usia produktif(15-64 tahun) yang memiliki Balita di Sumatera Barat, dan daerah penelitian adalah Kabupaten Agam dan Kabupaten Pasaman. Data yang digunakan adalah data primer dengan metode sensus, alat pengumpulan data dengan wawancara terstruktur menggunakan daftar pertanyaan (kuesioner). Metode analisa data dilakukan secara deskriptif dan induktif dengan peralatan analisis statistika dan ekonometrika. Hasil studi memperlihatkan bahwa penawaran tenaga kerja wanita yang memiliki balita dipengaruhi oleh variabelumur, tingkat pendidikan, jumlah ART, status RT, dan kedudukan pekerjaan suami. Dari studi ini juga ditemukan wanita memiliki balita cenderung memasuki lapangan kerja setelah anaknya cukup aman untuk ditinggalkan atau dibawa bekerja, penawaran tenaga kerja wanita berbalita bersifat komplementer terhadap pekerjaan suami.

Kata Kunci: Penawaran tenaga kerja, wanita memiliki balita, umur, pendidikan, dan pekerjaan suami.

Klasifikasi JEL : J01, J11, J17 dan J22.

Abstract

The purpose of this study to find the factors that affect the labor supply of women who have toddler in West Sumatra. The decision to enter the labor market that should be taken by women in general and women who have toddler in particular is complex, it depends on the individual's background and the influence of family and neighborhood. This study examine the factor of individual characteristics, family characteristics and the characteristics of the husband's work, the object of the study were women of childbearing age (15-64 years) in West Sumatra, the research area is Agam and Pasaman district. The data used are primary data with census method, while the data collection technique is a structured interview using a questionnaire. Data analysis method performed by descriptive and inductive statistical and econometric analysis tools. This study found that the labor supply of women have toddlers influenced by variables of age, education level, number of household members, household status and position husband's work. In addition, women with toddlers tend to enter the workforce after her child is safe to be abandoned or brought to work, therefore the labor supply woman who had a toddler is complementary to the husband's work.
\end{abstract}

Keywords: Labor Supply, women have toddler, age, education, and husband's work. JEL classification : J01, J11, J17 dan J22. 


\section{PENDAHULUAN}

Perlambatan ekonomi yang terjadi pada tahun 2015 di wilayah Sumatera Barat, berimbas pada menurunnya tingkat partisipasi angkatan kerja dan rasio pekerja tidak penuh pada periode Agustus 2015 di Sumatera Barat. Kondisi ini tampak dari kondisi ketenagakerjaan di Sumatera Barat yang ditandai dengan tingkat pengangguran yang meningkat. Jumlah pengangguran di Sumatera Barat pada Agustus 2015 mencapai 161,56 ribu orang, dengan Tingkat Pengangguran Terbuka (TPT) cenderung meningkat, dimana TPT Agustus 2015 sebesar 6,89 persen naik dari TPT Februari 2015 sebesar 5,99 persen dan TPT Agustus 2014 sebesar 6,50 persen. (BPS, 2015)

Wanita sebagai salah satu sumber daya manusia di pasar kerja mempunyai kontribusi yang besar, dimana jumlah wanita yang menawarkan tenaga untuk bekerja dari waktu ke waktu cenderung meningkat. Peningkatan penawaran tenaga kerja wanita di pasar kerja diantaranya dipengaruhi oleh keinginan untuk meningkatkan kesejahteraan keluarga, sebagai akibat keterbatasan suami untuk memenuhi kebutuhan hidup keluarganya.

Wanita pekerja di Indonesia pada umumnya bukanlah sebagai pencari nafkah utama, tetapi sebagai pencari pendapatan tambahan bagi keluarga (secondary workers), walaupun penghasilan yang diperoleh sering sangat membantu bahkan merupakan penunjang utama ekonomi rumah tangga. Namun demikian, motivasi penawaran tenaga kerja wanita di pasar kerja berbeda untuk setiap jenjang sosial ekonomi maupun tingkat pendidikan. Hal inilah yang menjadi salah satu faktor kajian tentang wanita selalu menarik perhatian para peneliti.

Dalam konteks penawaran tenaga kerja, pemilihan pengalokasian waktu menjadi dasar bagi individu untuk memutuskan berapa waktu yang akan digunakan untuk bekerja dan untuk leisure. Bagi tenaga kerja wanita yang sudah menikah, dan memiliki anak balita, pemilihan kombinasi alokasi waktu menjadi semakin kompleks. Tenaga kerja wanita yang memiliki balita harus mampu memilih pengalokasian waktu untuk berbagai aktifitas rumah tangga yang dianggap tidak produktif karena tidak menghasilkan pendapatan dengan aktivitas bekerja untuk memperoleh pendapatan serta waktu senggang untuk beristirahat.

Semakin kompleksnya masalah alokasi waktu bagi wanita memiliki Balita, khususnya di kawasan perdesaan Sumatera Barat yang berbudaya matriakhart mendorong penulis untuk mengkaji dan menganalisis faktor yang mempengaruhi mereka untuk masuk ke pasar kerja. Penelitian ini memfokuskan analisis pada penawaran tenaga kerja wanita yang memiliki Balita, dalam upaya mengalokasikan waktu untuk mendapatkan pendapatan bagi dirinya dan keluarganya dengan memperhatikan karakteristik sosial ekonomi angkatan kerja wanita, rumah tangga (keluarga), dan pekerjaan suami.

\section{TINJAUAN PUSTAKA}

\section{Teori Alokasi Waktu}

Becker (1965) dalam karyanya $A$ Theory of the Allocation of Time menyatakan bahwa setiap individu memiliki waktu yang akan dialokasikan untuk bekerja ataupun untuk kegiatan lainnya. Dengan total waktu (T) yang dimiliki sama untuk setiap individu yaitu sebanyak 24 jam, tentu saja waktu tidak hanya digunakan untuk bekerja saja atau hanya dialokasikan untuk kegiatan makan, tidur, rekreasi. Waktu akan dialokasikan untuk kegiatan memaksimumkan pendapatan dan leisure (bersantai). Penurunan pendapatan akan mempengaruhi penurunan waktu di kegiatan konsumsi karena waktu akan menjadi semakin mahal.

Jika waktu yang digunakan untuk bekerja sebanyak h jam, maka waktu luang (Leisure) yang dimiliki adalah sebesar (24-h) jam perhari (Sudarsono dalam Marhaeni dan Manuati, (2004), Tarmizi, (2012).). Waktu luang ini akan digunakan untuk makan, tidur, mengurus rumah, mengasuh anak, rekreasi dan sebagainya. Secara ekonomi dapat dikatakan orang yang menggunakan waktuya untuk waktu luang dapat disebut mengkonsumsi waktu luang dan dia akan memperoleh kepuasan atau utilitas, sedangkan individu yang menggunakan sebagian waktunya utuk bekerja juga akan memperoleh kepuasan atau utilitas karena dapat mengkonsumsi 
barang dan jasa dari upah yang didapat karena bekerja.

Keputusan untuk bekerja pada dasarnya adalah sebuah keputusan tentang bagaimana menggunakan waktu yang dimiliki. Setiap individu dapat menggunakan waktu yang tersisa untuk aktivitas-aktivitas leisure seperti aktif dalam kegiatan sosial, budaya, mengurus rumah tangga, mengurus anak ataupun untuk berlibur sambil menjalankan hobi dari individu tersebut.

Adapun hal lain yang dapat mempengaruhi waktu untuk bekerja antara lain jumlah beban tanggungan, kepemilikan pendapatan non kerja, bahkan budaya suatu daerah juga dapat menentukan keterlibatan perempuan dalam pasar kerja (Marhaeni dan Manuati, 2004), pada kenyataannya tiap individu mencoba menyeimbangkan antara pekerjaan dan kegiatan rumah (Grant dan Stewart, 2001).

Tenaga kerja merupakan faktor terpenting dalam proses produksi khususnya dan perekonomian pada umumnya. Sebagai faktor produksi, tenaga kerja memainkan peran lebih penting dari pada faktor produksi yang lain seperti bahan mentah, tanah, air, dan sebagainya, karena tenaga kerja adalah faktor produksi yang berperan penting dalam menggerakkan facktor produksi lainnya untuk menghasilkan komoditas dalam perekonomian. Menurut UU No. 13 Tahun 2003 tentang Ketenagakerjaan, tenaga kerja adalah setiap orang yang mampu melakukan pekerjaan guna menghasilkan barang dan atau jasa baik untuk memenuhi kebutuhan sendiri maupun untuk masyarakat.

Penawaran tenaga kerja pada dasarnya memiliki dua dimensi utama (Tarmizi, 2012; Ehrenberg and Smith, 2012) yaitu dimensi jam kerja dan dimensi tingkat partisipasi. Dimensi jam kerja didasarkan pada Teori penawaran tenaga kerja Neoclasic, dimana setiap individu dihadapkan pada pilihan Labor-Leasure (Kauffman, 2003), atau Income-Leasure (Gunderson \& Graig, 1993), dalam hal ini setiap individu akan dihadapkan pada pilihan bekerja atau tidak bekerja dalam memanfaatkan waktunya, dimensi ini merupakan dimensi mikro.

Dimensi jam kerja merupakan permasalahan penawaran tenaga kerja jangka pendek sedangkan dimensi partisipasi merupakan permasalahan penawaran tenaga kerja jangka panjang. Dalam jangka pendek diasumsikan setiap individu memiliki tingkat skill yang sama sehingga fokus analisis hanya pada jam kerja, jika ada perubahan tingkat upah maka setiap individu akan merespon dengan melakukan perubahan pada berapa lama waktu yang akan digunakan untuk bekerja dan untuk leisure. Sedangkan dalam jangka panjang, permasalah yang terjadi akan lebih kompleks dan membutuhkan penyesuaian yang juga semakin kompleks, dimana di dalam jangka panjang akan terjadi perubahan jumlah, rasio jenis kelamin, dan komposisi penduduk, serta kondisi sosial, ekonomi dan politik, hal inilah yang nantinya akan mempengaruhi tingkat partisipasi angkatan kerja di suatu daerah.

Bagi seorang perempuan yang sudah kawin dan memiliki keluarga, pilihan bekerja untuk mendapatkan upah atau gaji seringkali berbenturan dengan pekerjaan mengurus rumah tangga dan keluarga tanpa mendapatkan upah. Bagaimana kondisi angka Tingkat Partisipasi Angkatan Kerja (TPAK) perempuan dalam suatu masyarakat akan sangat dipengaruhi oleh aspek sosial budaya dan modernisasi dalam hubungannya dengan hakekat bekerja di dalam tatanan masyarakat yang bersangkutan.

\section{Penawaran Tenaga Kerja Wanita Kawin}

Partisipasi kaum wanita dalam angkatan kerja di negara-negara dunia ketiga telah meningkat secara dramastis semenjak tahun 1990 di mana untuk negara-negara Asia meningkat sampai 4,3\%. Tetapi kebanyakan kaum wanita tersebut hanya bekerja di tempat-tempat yang tidak banyak menghasilkan pendapatan, mereka terpusat di sektor pertanian sebanyak $80 \%$ atau sektor-sektor informal perkotaan 25 hingga $40 \%$. Kaum wanita hampir selalu mengalami diskriminasi dalam hal perolehan imbalan dan peningkatan dalam pekerjaan (Todaro, 2011).

Peningkatan jumlah wanita yang bekerja disebabkan oleh dua faktor utama, yaitu terjadinya peningkatan dari penawaran dan pemintaan. Dari sisi penawaran disebabkan oleh semakin membaiknya tingkat pendidikan wanita. Hal tersebut didorong oleh kondisi dimana semakin besarnya masyarakat yang 
menerima wanita bekerja di luar rumah. Sedangkan dari sisi permintaan, tenaga kerja wanita diperlukan dalam proses produksi seperti industri tekstil dan garmen. Sedangkan fenomena lain yang mendorong masuknya wanita ke lapangan pekerjaan adalah karena semakin tingginya biaya hidup jika hanya ditanggung oleh pendapatan keluarga yang rendah (ILO, 2015).

Maryanti (2000) meneliti tentang Analisa Faktor-faktor yang Mempengaruhi TPAK Wanita di Perkotaan menurut Provinsi di Indonesia Tahun 2000. Hasil penelitian menunjukkan bahwa semakin besar jumlah anak yang masih hidup makin kecil TPAK kaum wanita. Proporsi penduduk yang berpendidikan SLTA ke atas memiliki pengaruh terhadap TPAK, tetapi Jam Kerja perminggu tidak mempunyai pengaruh terhadap TPAK, lapangan pekerjaan mempunyai pengaruh terhadap TPAK, Proporsi penduduk usia produktif tidak memperlihatkan hubungan terhadap TPAK di kota maupun di desa.

Wirawan (2003) meneliti tentang faktorfaktor yang mempengaruhi tingkat partisipasi angkatan kerja wanita di Kabupaten Hulu Sungai Selatan Provinsi Kalimantan Selatan. Variabel yang diamati adalah variabel umur, tingkat pendidikan, jumlah tanggungan keluarga dan upah. Hasil menunjukkna bahwa bahwa seluruh variabel signifikan mempengaruhi partisipasi angkatan kerja wanita di Kabupaten Hulu Sungai Selatan Provinsi Kalimantan Selatan. Variabel yang paling kuat mempengaruhi partisipasi angkatan kerja wanita adalah tingkat pendidikan dan jumlah tanggungan keluarga.

Kajian yang dilakukan oleh Kurniati pada tahun 2012 tentang "Analisis Penawaran Tenaga Kerja Wanita Menikah Sektor Informal di Kota Makassar', menemukan bahwa variabel pendapatan responden dan variabel jumlah tanggungan berpengaruh positif dan signifikan terhadap jam kerja yang ditawarkan wanita. Sedangkan variabel umur memiliki pengaruh yang negative tetapi tidak signifikan terhadap penawaran jam kerja wanita. Adapun variabel pendidikan memiliki pengaruh yang positif dan signifikan terhadap jam kerja.
Pada tahun 2012, Putri dan Purwanti melakukan studi tentang faktor yang mempengaruhi Penawaran Tenaga wanita di Kabupaten Brebes. Hasil studi ini menunjukkan bahwa upah/pendapatan dan pengeluaran rumah tangga menunjukan pengaruh yang positif sedangkan penghasilan suami, usia, pendidikan, jumlah anak balita berpengaruh negatif terhadap penawaran tenaga kerja wanita yang menikah di kabupaten Brebes.

Kajian pada tahun 2015 yang dilakukan oleh Guner, dkk, di Barcelona menemukan bahwa dengan adanya penambahan tenaga kerja wanita, tingkat pengangguran berkurang sebesar $0,3 \%$ di kalangan angkatan kerja wanita. Studi Giannakopoulos (2015) di Yunani menemukan wanita kawin di wilayah ini meningkatkan penawaran tenaga kerjanya ketika suaminya kehilangan pekerjaan sebagai dampak krisis yang terjadi, akan tetapi penambahan yang terjadi tidak terlalu siginifikan, hal ini diperlihatkan oleh perbedaan peningkatan tingkat pengangguran yang terjadi dengan tingkat penambahan tenaga kerja, dimana peningkatan tenaga kerja laki-laki dimasa krisis lebih tinggi dari pada peningkatan partisipasi tenaga kerja wanita, meskipun di dalam jangka pendek (data bulanan) respon penawaran tenaga kerja wanita kawin cukup besar namun di dalam jangka panjang (data tahunan) cenderung menurun.

Ortega (2015) menemukan bahwa penawaran tenaga kerja wanita sebagai akibat suami kehilangan pekerjaan lebih besar terjadi di kawasan perkotaan dari pada kawasan perdesaan, hal ini mengindikasikan bahwa guncangan akibat krisis lebih besar dirasakan oleh masyarkat perkotaan dari pada masyarakat di perdesaan. Sedangkan studi di Jerman yang dilakukan oleh tim peneliti dari DIW SOEP, Berlin di tahun yang sama, menemukan bahwa probabilitas penambahan penawaran tenaga kerja wanita kawin lebih tingi terjadi pada individu yang memiliki pasangan kehilangan pekerjaan dari pada individu yang memiliki pasangan bekerja.

Mengacu dari berbagai studi yang telah dianalisis di atas, maka dalam kajian ini penulis akan menganalisis variabel pendidikan dan umur sebagai faktor karakteristik 
individu yang mempengaruhi keputusan wanita berbalita memutuskan untuk bekera, sedangkan karakteristik rumah tangga dilihat dari jumlah anggota rumah tangga dan status rumah tangga, adapun karakteristik pekerjaan suami difokuskan pada status dan kedudukan pekerjaan suami, dengan demikian dalam hal ini berarti suami berstatus bekerja.

\section{METODE PENELITIAN}

Penelitian ini menggunakan pendekatan penelitian deskriptif kuantitatif dan pendekatan deduktif. Pendekatan deduktif merupakan pendekatan yang menggunakan logika untuk menarik satu atau lebih kesimpulan berdasarkan seperangkat premis yang diberikan berdasarkan teori yang ada, pendekatan deduktif digunakan untuk pengambilan kesimpulan dari sesuatu yang bersifat umum menjadi sesuatu yang bersifat khusus. Sedangkan penelitian deskriptif merupakan kajian yang menganalisis dan menggambarkan kondisi dari objek penelitian dan penelitian kuantitatif adalah penelitian yang menekankan pada pengujian teoriteori melalui pengukuran variabel-variabel penelitian yang diukur dengan angka atau indikator kuantitatif. Selanjutnya, variabel penelitian akan dianalisis dengan prosedur statistik, untuk membuktikan hipotesis dan mencapai mencapai tujuan penelitian.

Data yang digunakan dalam penelitian ini adalah data primer dan data sekunder dari publikasi BPS dan lembaga terkait lainnya serta literatur pendukung. Data yang digunakan adalah data cross section, yang diambil dari daerah Kabupaten Agam dan Kabupaten Pasaman yang mewakili kawasan perdesaan Sumatera Barat. Kabupaten Agam merupakan kawasan perdesaan yang mewakili daerah yang relatif lebih maju, dengan dinamika ekonomi yang lebih tinggi sedangkan kabupaten Pasaman merupakan kawasan perdesaan yang relatif kurang maju.

Pengumpulan data primer dilakukan dengan menggunan kuesioner yang sudah disiapkan sedangkan sampel diambil dengan metode sensus, data responden diperoleh berdasarkan data dari kader desa tentang wanita yang memiliki Balita. Selanjutnya semua wanita yang memiliki balita didatangi dan diwawancarai dengan menggunakan kuesioner yang telah disiapkan. Dari hasil pencacahan diperoleh 646 responden.

Selanjutnya, dengan memperhatikan semua kemungkinan penggunaan waktu oleh wanita kawin (istri), dan asumsi bahwa tingkat upah di pasar konstan, maka tingkat partisipasi tenaga kerja wanita hanya akan focus penawaran jam kerja. Sedangkan persamaan model penelitian ini diadob dari model penelitian yang diterapkan oleh Kohara (2008), dengan bentuk dasar persamaan adalah:

$$
W L_{i t}=\sum_{j=1} \alpha_{1} C W L_{i t}+\sum_{j=1} \alpha_{2} C H_{i t}+\sum_{j=1} C X_{i t}+e_{i t}
$$

$$
\begin{array}{ll}
\text { Dimana: } & \\
\text { WLit } & =\text { Penawaran Tenaga Kerja Wanita } \\
& \text { memiliki Balita } \\
\mathrm{CWL}_{\text {it }} & =\text { Karakteristik individu Tenaga Kerja } \\
& \text { Wanita Kawin (istri) } \\
\mathrm{CH}_{\mathrm{it}} & =\text { Karakteristik pekerjaan suami } \\
\mathrm{CX}_{\mathrm{it}} & =\text { Karakteristik Rumah Tangga Wanita } \\
& \text { Kawin (istri) } \\
\mathrm{e}_{\mathrm{it}} & =\text { Error term }
\end{array}
$$

Persamaan di atas, selanjutnya diestimasi dengan menggunakan analisis ekonometrika dengan model Logit, khususnya logistic binary regression. Adapun bentuk umum persamaan logistic adalah:

$$
\pi(x)=\frac{\exp \left(\beta_{0}+\beta_{1} x_{1}+\beta_{2} x_{2}+\ldots . . \beta_{k} x_{k}\right)}{1+\exp \left(\beta_{0}+\beta_{1} x_{1}+\beta_{2} x_{2}+\ldots . . \beta_{k} x_{k}\right)}
$$

Dimana $\pi(x)=$ adalah peluang sukses probabilita suatu peristiwa yang ditentukan oleh $\mathrm{y}=1$, sedangkan $\beta$ i adalah nilai koefisien/ parameter variabel penjelas. Bentuk fungsi linier dari persamaan (2) adalah:

$g(x)=\ln \left[\frac{\pi(x)}{1-\pi(x)}\right]=\beta_{0}+\beta_{1 X 1}+\beta_{2 X}+\ldots \ldots . . \beta_{k X k}$

Dimana $\frac{\pi(\mathrm{x})}{1-\pi(\mathrm{x})}$ merupakan rasio dari $\mathrm{y}=1$ untuk $\mathrm{x}$ tertentu.

Model penelitian ini adalah : 
Tabel 1. Pengukuran Variabel Penelitian

\begin{tabular}{|c|c|c|c|}
\hline Nama Variabel & Simbol Variabel & Defenisi Operasional & Satuan /Ukuran Variabel \\
\hline \multicolumn{4}{|l|}{ Variabel Terikat } \\
\hline $\begin{array}{l}\text { Penawaran Tenaga } \\
\text { Kerja Wanita Kawin }\end{array}$ & $\mathrm{y}_{\mathrm{it}}$ & $\begin{array}{l}\text { Status Pekerjaan Wanita } \\
\text { Kawin }\end{array}$ & $\begin{array}{l}1=\text { Bekerja } \\
0=\text { Tidak Bekerja }\end{array}$ \\
\hline \multicolumn{4}{|l|}{ Variabel Bebas } \\
\hline \multirow[t]{2}{*}{$\begin{array}{l}\text { Karakteristik individu } \\
\text { Wanita Kawin }\end{array}$} & \multirow[t]{2}{*}{$\mathrm{X}_{\text {lit }}$} & Umur Wanita Kawin & $\begin{array}{l}1=\text { Umur } \geq 40 \text { tahun } \\
0=\text { Umur }<40 \text { tahun }\end{array}$ \\
\hline & & Pendidikan Wanita Kawin & $\begin{array}{l}1=\text { Pendidikan } \geq \text { SLTP } \\
0=\text { Pendidikan }<\text { SLTP }\end{array}$ \\
\hline \multirow[t]{2}{*}{$\begin{array}{l}\text { Karakteristik Rumah } \\
\text { Tangga }\end{array}$} & \multirow[t]{2}{*}{$\mathrm{X}_{2 \mathrm{it}}$} & $\begin{array}{l}\text { Jumlah anggota rumah } \\
\text { tangga }\end{array}$ & $\begin{array}{l}1=\text { Jumlah ART } \geq 4 \\
0=\text { Jumlah ART }<4\end{array}$ \\
\hline & & Status Rumah Tangga & $\begin{array}{l}1=\mathrm{RT} \text { miskin } \\
0=\mathrm{RT} \text { tidak miskin }\end{array}$ \\
\hline \multirow[t]{2}{*}{$\begin{array}{l}\text { Karakteristik Pekerjaan } \\
\text { Suami }\end{array}$} & \multirow[t]{2}{*}{$\mathrm{X}_{3 \mathrm{it}}$} & $\begin{array}{l}\text { Status Lap. Pekerjaan } \\
\text { Suami }\end{array}$ & $\begin{array}{l}1=\text { Non Formal } \\
0=\text { Formal }\end{array}$ \\
\hline & & $\begin{array}{l}\text { Kedudukan Pekerjaan } \\
\text { Suami }\end{array}$ & $\begin{array}{l}1=\text { Buruh/Karyawan } \\
0=\text { Mandiri/profesional }\end{array}$ \\
\hline
\end{tabular}

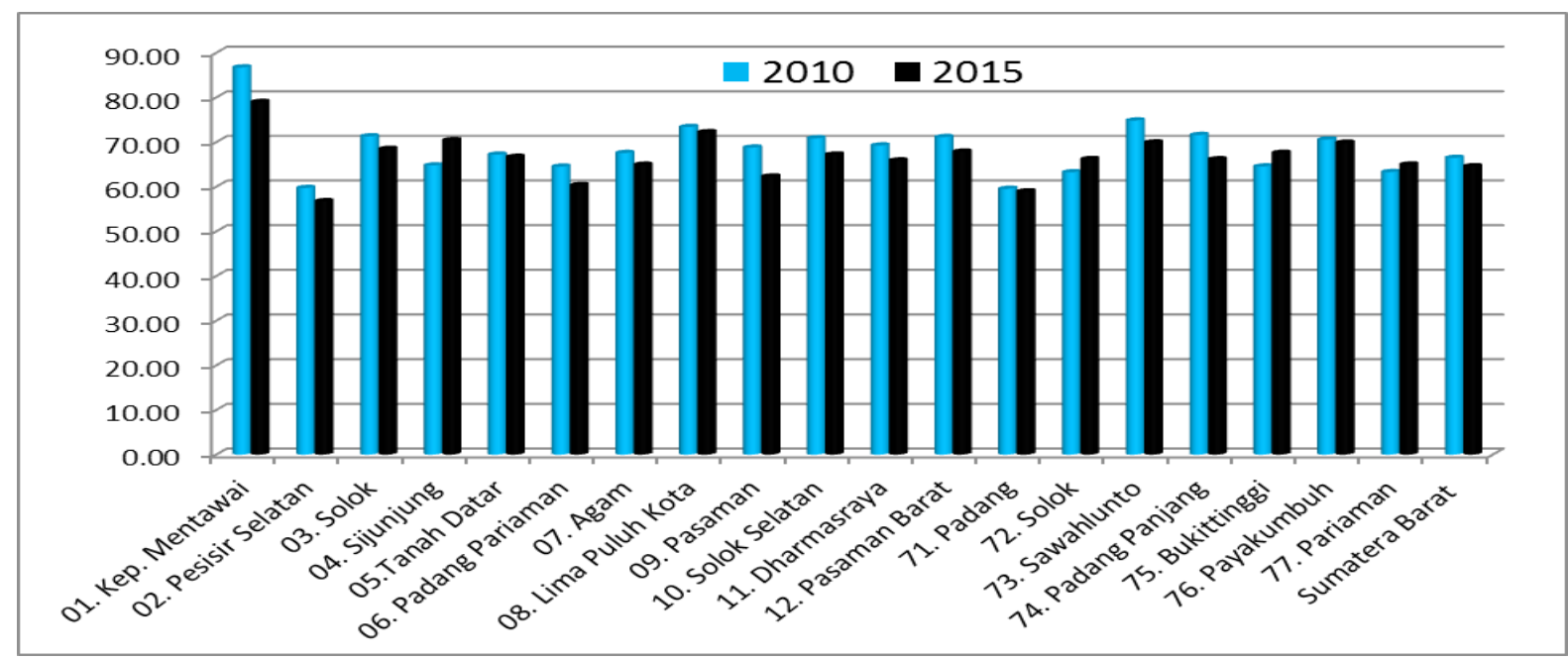

Gambar 1. TPAK Menurut Kabupaten/Kota Tahun 2010-2015

Sumber: BPS Sumbar

$g(X)=\ln \left[\frac{\pi(X)}{1-\pi(X)}\right]=\beta_{0}+\beta_{1 X 1}+\beta_{2} X_{2}+\beta_{3} X_{3}+\beta_{4} X_{4}+\beta_{5} X_{5}+\beta_{6} X_{6}$

Dimana : $\quad \mathrm{X}_{1}=$ Umur

$\mathrm{X}_{2}=$ Tingkat pendidikan

$\mathrm{X}_{3}=$ Jumlah ART

$\mathrm{X}_{4}=$ Status RT

$\mathrm{X}_{5}=$ status Lapangan Pekerjaan suami

$\mathrm{X}_{6}=$ Status Kedudukan Pekerjaan suami
Adapun pengukuran dari variabel yang diamati dalam penelitian ini dapat dilihat pada tabel 1.

\section{HASIL DAN PEMBAHASAN}

\section{Karakteristik Ketenagakerjaan Sumatera Barat}

TPAK (Tingkat Partisipasi Angkatan Kerja) di Sumatera Barat memperlihatkan kecenderungan penurunan pada tahun 2015 dibandingkan dengan kondisi tahun 2015, dimana pada tahun 2010 TPAK adalah 66,44\% sedangkan pada tahun 2015 TPAK 


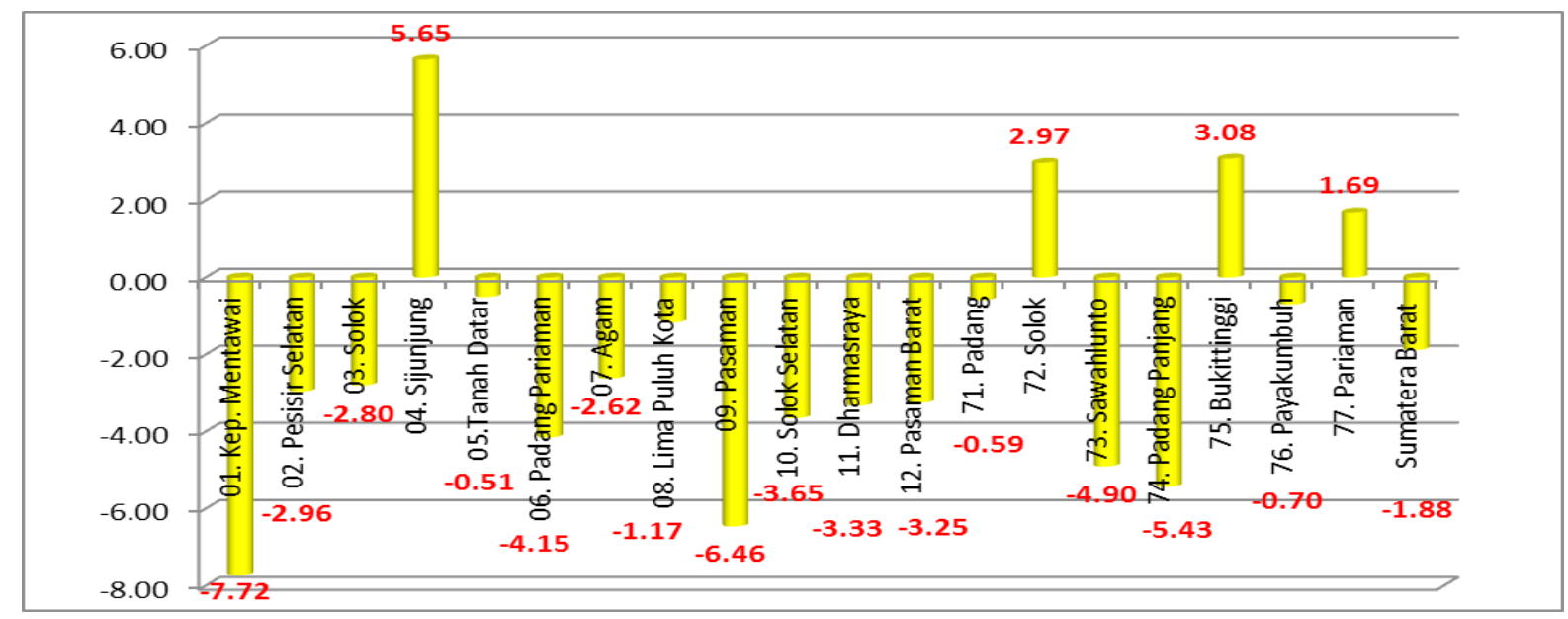

Gambar 2 Perkembangan TPAK Menurut Kabupaten/Kota Tahun 2010-2015

Sumber: BPS Sumbar.

adalah $64,56 \%$. Hal ini mengindikasikan bahwa penyerapan tenaga kerja di Sumatera Barat masih rendah.

Jika dilihat menurut kabupaten kota, peningkatan TPAK pada periode tahun 2010-2015 hanya terjadi di 4 (empat) daerah, yakni Kabupaten Sijunjung yang mengalami peningkatan TPAK tertinggi sebesar 5,65\%, diikuti oleh Kota Bukittinggi dengan peningkatan TPAK sebesar 3,08\%, selanjutnya adalah Kota Solok dan Kota Pariaman dengan peningkatan TPAK masingmasingnya $2,97 \%$ dan $1,69 \%$.

Daerah yang mengalami penurunan TPAK paling besar adalah Kabupaten Mentawai, dengan penurunan sebesar 7,72\%, sedangkan yang terendah adalah Kabupaten Tanah Datar dengan penurunan sebesar $0,51 \%$. Secara keseluruhan penurunan TPAK Sumatera Barat adalah 1,88\%. Kondisi ini mengindikasikan bahwa secara umum perekonomian kabupaten/kota di Sumatera Barat masih memiliki kemampuan yang terbatas dalam penciptaan lapangan pekerjaan.

Keterbatasan kemampuan suatu perekonomian dalam penyerapan tenaga kerja tentunya akan membawa dampak negative terhadap perekonomian di masa depan, karena akan meningkatkan pengangguran yang dapat menimbulkan berbagai masalah sosial ekonomi dalam kehidupan masyarakat. Untuk itu upaya peningkatan aktivitas ekonomi tentunya harus dilakukan oleh semua pemerintah daerah kabupaten/kota dan pemerintah provinsi untuk mendorong perekonomian dan peningkatan kesejahteraan masyarakatnya.

Dilihat dari tingkat pendidikan tampak bahwa terjadi peningkatan yang cukup besar pada pengangguran dengan pendidikan SLTP, hal ini mengindikasikan bahwa wajib sekolah sembilan tahun telah berhasil di wilayah Sumatera Barat, namun lapangan kerja yang tersedis untuk tanaga kerja ini masih terbatas, akibatnya terjadi pengangguran yang cukup besar. Peningkatan jumlah pengangguran juga terjadi pada tingkat pendidikan Diploma/ Akademi. Hal ini disebabkan terjadinya peningkatan tenaga lulusan Diploma/Akademi lebih tinggi dari pada tingkat penyerapan perekonomian daerah. Dari kondisi ini dapat dilihat bahwa peningkatan pengangguran di Sumatera Barat berasal dari peningkatan pengangguran dengan pendidikan SLTP dan Diploma/Akademi.

Dilihat dari lapangan kerja utama tampak bahwa lapangan kerja yang memiliki daya serap tertinggi terhadap tenaga kerja adalah lapangan usaha pertanian, selama periode 2010-2015 meski terjadi penurunan namun masih mendominasi penyerapan tenaga kerja di Sumatera Barat. Hal ini memperlihatkan bahwa perekonomian daerah masih berbasis sektor primer. Lapangan usaha lainnya yang menjadi penyerap tenaga kerja yang cukup tinggi adalah lapangan usaha perdagangan, rumah makan dan jasa akomodasi, diikuti oleh lapangan usaha jasa kemasyarakatan, Sosial dan perorangan, seperti yang diperlihatkan oleh gambar 4 


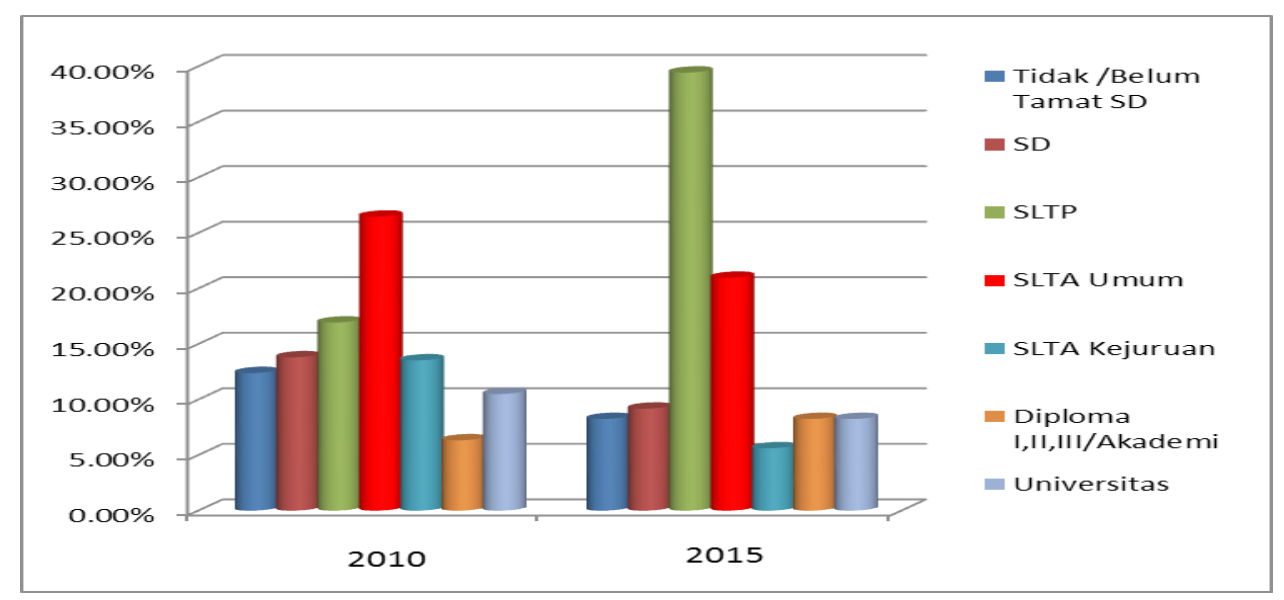

Gambar 3. TPT Provinsi Sumatera Menurut Tingkat Pendidikan Tahun 2010-2015

Sumber: BPS Sumbar.

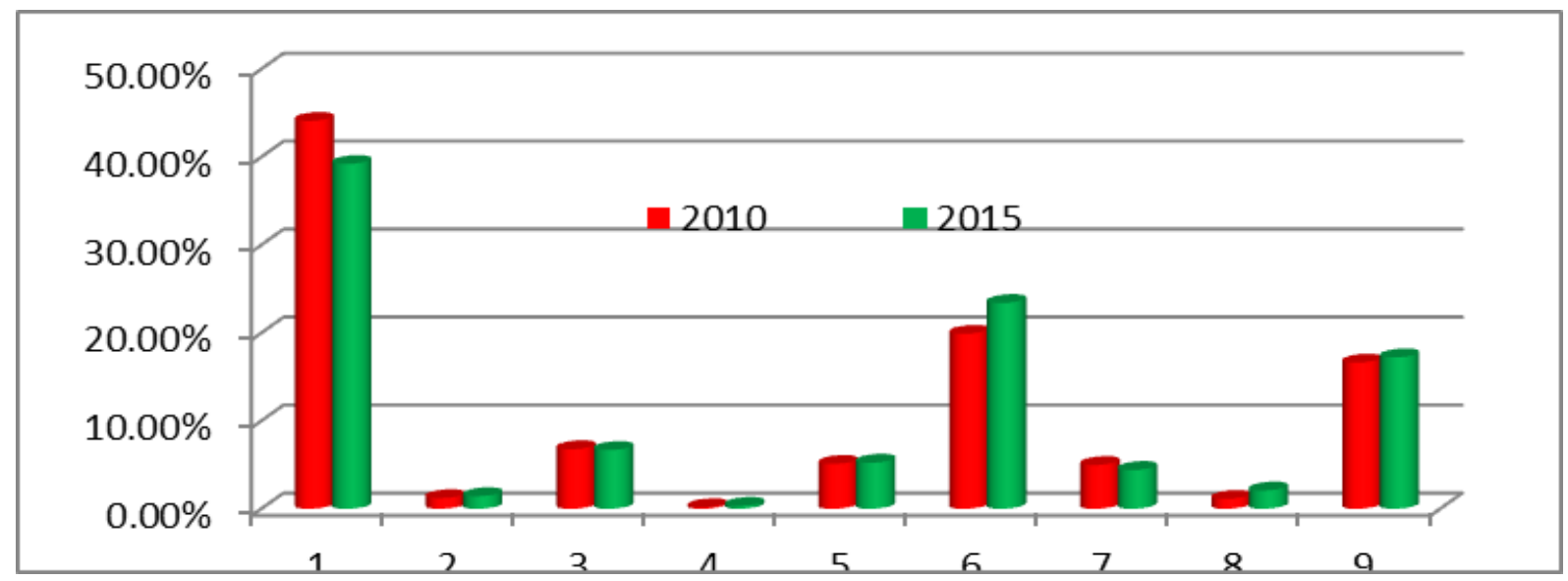

Gambar 4 Penduduk 15 Tahun Ke Atas yang Bekerja Menurut Lapangan Pekerjaan Utama Tahun 2010-2015

Sumber: BPS Sumbar.

Keterangan:

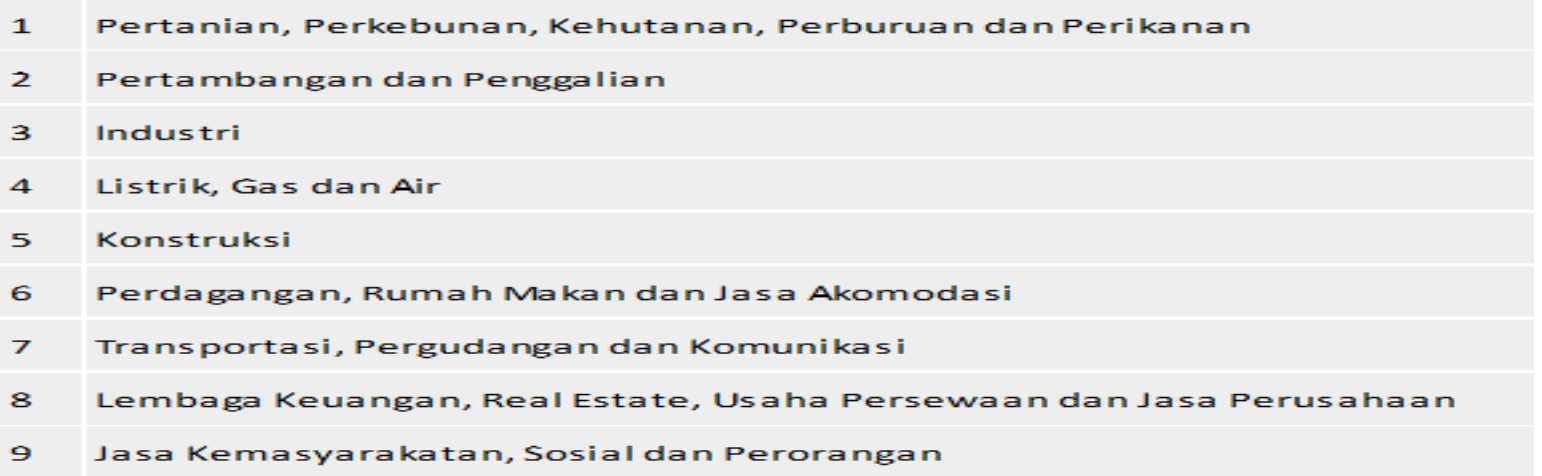

\section{Temuan Empiris}

Hasil pengolahan data menemukan koefisien untuk variabel bebas yang diamati yang diperlihatkan oleh table 2 . Ada enam variabel bebas yang diteliti yakni variabel umur dan pendidikan terakhir yang ditamatkan sebagai variabel karakteristik individu, variabel status rumah tangga dan jumlah anggota rumah tangga untuk melihat karakteristik rumah tangga sedangkan variabel status lapangan pekerjaan suami dan kedudukan pekerjaan sebagai variabel karakteristik pekerjaan suami. 
Tabel 2. Hasil Estimasi Model Penelitian

\begin{tabular}{|l|c|c|c|c|c|}
\hline \multicolumn{1}{|c|}{ Dependent Variables } & B & S.E. & Wald & Sig. & Exp(B) \\
\hline X1 (Umur) & .601 & .270 & 4.937 & .026 & 1.824 \\
X2 (Pendidikan) & .688 & .182 & 14.270 & .000 & 1.503 \\
X3 (Jumlah ART) & -.135 & .193 & .490 & .004 & .874 \\
X4 (Status RT) & .068 & .207 & .108 & .022 & 1.071 \\
X5 (Status Lapangan & .030 & .304 & .010 & .622 & 1.030 \\
Pekerjaan Suami) & & .205 & .621 & .031 & 1.175 \\
X6 (Status Kedudukan & .162 & .205 & & .028 \\
Pekerjaan Suami) & -.848 & .255 & 11.099 & .001 & .428 \\
Constant
\end{tabular}

Sumber: Hasil pengolahan data lapangan

Dari hasil estimasi di atas, dapat dibuat persamaan hasil estimasi sebagai berikut:

$g(x)=\ln \left[\frac{\pi(x)}{1-\pi(x)}\right]=\beta 0+\beta 1 \times 1+\beta 2 \times 2+\beta 3 \times 3+\beta 4 \times 4+\beta 5 \times 5+\beta 6 \times 6$

$g(x)=\ln \left[\frac{\pi(x)}{1-\pi(x)}\right]=-0,848+0,0,001 \times 1+0,068 \times 2-0,135 \times 3+0,068 \times 4+0,30 \times 5+0,162 \times 6$

Dari nilau uji Hosmer dan Lemeshow dapat dilihat bahwa persamaan logitik binary yang dihasilkan layak dipakai karena $0,406>0,05$; sehingga persamaan ini dapat digunakan sebagai alat analisis untuk membuktikan hipotesis penelitian yang telah dibuat.

Hasil estimasi memperlihatkan bahwa faktor umur mempunyai pengaruh yang posisitf dan signifikan terhadap penawaran tenaga kerja wanita kawin memiliki balita, dimana peluang wanita berusia kurang dari 40 tahun untuk memasuki lapangan kerja 1,8kali lebih besar dibandingkan wanita yang berusia di atas 40 tahun.

Tingkat pendidikan memiliki pengaruh yang posisitf dan signifikan terhadap penawaran tenaga kerja wanita memiliki balita, semakin tinggi tingkat pendidikan maka semakin besar probabilita wanita memiliki balita untuk masuk ke pasar kerja. Dimana, tingkat pendidikan di atas SLTP memiliki peluang 1,503 kali lebih tinggi dibandingkan mereka yang berpendidikan lebih rendah dari SLTP.

Jumlah ART berpengaruh negatif dan siginifikan, hal ini mengindikasikan bahwa jumlah anggota rumah tangga yang besar terutama yang masih berusia balita akan menyulitkan ibu rumah tangga untuk memasuki dunia kerja. Dengan semakin besarnya jumlah ART maka semakin sulit bagi wanita memiliki balita untuk masuk ke pasar kerja. Probabilitas wanita memiliki balita dengan jumlah rumah tangga lebih besar dari 4 orang akan 0,8 lebih rendah dibandingkan dengan mereka yang memiliki anggota rumah tangga kurang dari empat orang.

Untuk variabel status RT hasil studi memperlihatkan bahwa variabel ini memiliki pengaruh yang positif dan signifikan, dimana jika wanita berasal dari rumah tangga miskin akan memiliki probabilita lebih besar masuk ke pasar kerja, yakni sebesar 1,071. Hal ini menggambarkan bahwa kebutuhan ekonomi mendorong wanita memiliki balita untuk memasuki dunia kerja untuk dapat membantu memenuhi kebutuhan keluarga mereka.

Dari variabel karakterisrik pekerjaan suami, ditemukan bahwa variabel status lapangan pekerjaan pengaruhnya tidak signifikan, hal ini berarti bahwa disektor formal ataupun non-formal seorang suami bekerja tidak akan berpengaruh pada penawaran tenaga kerja istri yang memiliki balita. Sedangkan variabel status kedudukan pekerjaan suami menunjukkan pengaruh yang posisitif dan signifikan. Kondisi ini berarti bahawa jika suami adalah buruh atau karyawan yang menerima upah maka probabilitas istri yang memliki balita untuk memasuki sunia kerja semakin besar dibandingkan jika suami adalah pekerja mandiri atau professional, dimana probabilitasnya lebih besar 1,175 dari mereka yang memiliki suami sebagai buruh/ karyawan. 
Temuan studi ini sejalan dengan kajian Todaro (2000) di Negara sedang berkembang yang menemukan bahwa wanita cenderung bekerja di lapangan usaha pertanian dan lapangan usaha informal karena keterbatasan pendidikan dan keterampilan serta keharusan untuk membagi waktu antara bekerja di pasar kerja dan di bekerja rumah tangga di rumah.

Hasil studi ini juga sejalan dengan studi Maryanti (2000) yang menemukan bahwa jumlah anggota rumah tangga memiliki pengaruh negatif terhadap penawaran tenaga kerja wanita, dimana jumlah anak yang dimiliki akan menjadi beban kerja di rumah tangga bertambah sehingga wanita yang bersangkutran akan semakin kecil kemungkinannya untuk memasuki dunia kerja karena waktu yang tersedai telah terpakai untuk mengurus anak dan keluarganya sehingga sisa waktu untuk bekerja semakin kecil. Sedangkan studi Kurniati (2012) menemukan hasil yang berbeda dimana jumlah tanggungan memiliki pengaruh yang posisitf terhadap penawaran tenaga kerja wanita kawin sektor informal di Kota Makassar.

Untuk karakteritik pekerjaan suami, studi ini memiliki konteks yang berbeda dengan studi terdahulu, karena kajian ini menggunakan data mikro yaitu data rumah tangga yang dipereoleh dengan wawancara lansung, sedangkan kajian terdahulu menganalisis variabel pekerjaan suami dalam konteks makro, dimana akibat krisis ekonomi suami kehilangan pekerjaan sehingga istri akan terdorong untuk menggantikan (mensubstitusi) masuk ke pasar kerja untuk menjaga keberlanjutan ekonomi keluarganya. Dalam studi ini kajian dilakukan bukan dalam konteks makro ekonomi, melainkan dalam konteks mikro dan studi ini menemukan bahwa antara suami dan istri khususnya dengan variabel status kedudukan pekerjaan suami ada hubungan yang positif, dengan kata lain status kedudukan kerja suami mendorong waniat atau istri untuk masuk ke pasar kerja. Sehingga seorang istri bekerja bukan hanya karena suaminya kehilangan pekerjaan tetapi karena ingin membantu suami yang bekerja sebagai buruh atau pekerja yang diupah. Sehingga ada hubungan saling melengkapi (komplementer) diantara suami dan istri dalam bekerja dalam rangka memenuhi kebutuhan keluarganya. Hal ini menunjukkan istri di kawasan perdesaan Sumatera Barat bukanlah pencari nafkah utama rumah tangga melainkan sebagai pendukung ekonomi keluarganya.

\section{KESIMPULAN}

Catatan penting yang dapat dirumuskan dari hasil kajian ini adalah; lapangan usaha yang memiliki daya serap tertinggi terhadap tenaga kerja di Sumatera Barat adalah lapangan usaha pertanian, dengan status usaha pekerjaan sektor informal masih cukup besar berperan dalam penyerapan tenaga kerja dan penciptaan lapangan kerja di Sumatera Barat. Hal ini mengindikasikan potensi pengangguran tersembunyi masih cukup besar di daerah ini.

Penawaran tenaga kerja wanita memiliki balita di Sumatera Barat dipengaruhi oleh karakteristik individu yaitu variabel umur dan pendidikan, karakteristik rumah tangga diperlihatkan oleh jumlah anggota keluarga dan status rumah tangga, serta karakteristik pekerjaan suami yang ditunjukkan oleh status kedudukan pekerjaan suami. Dimana wanita memiliki balita bekerja sebagai komplementer bagi pekerjaan suami, dengan bekerja sebagai tenaga pendukung dalam pekerjaan suami, dan pada umumnya tidak menerima upah oleh karena itu sulit menghitung nilai pendapatan yang diperolehnya.

Untuk mendorong partisipasi kaum wanita khususnya yang telah memiliki Balita memasuki lapangan kerja, maka perlu dipertimbangkan kendala yang dihadapi, untuk itu faktor yang perlu diperhatikan adalah tempat bekerja sebaiknya tidak terlalu jauh dari rumah sehingga wanita atau ibu balita dapat dengan mudah kembali ke rumah untuk mengawasi kondisi si anak. Selanjutnya, ibu memiliki Balita sebaiknya bekerja paruh waktu sehingga dapat membagi waktu antara bekerja produktif dengan melakukan kewajiban domestiknya dalam rumah tangga

Untuk dapat mengembangkan usaha mandiri, diperlukan bantuan pembinaan dan pendampingan serta permodalan bagi wanita memiliki Balita di perdesaan Sumatera Barat agar mereka bisa melakukan usaha yang lebih 
produktif tidak hanya sebagai pembantu pekerjaan suami, guna meningkatkan pendapatan keluarga. Di samping itu, wanita memiliki balita harus mampu membagi waktu dengan baik antara waktu bekerja domestic dengan bekerja produktif agar tidak berakibat buruk terhadap tumbuh kembang balita, untuk itu peran dan bantuan anggota keluarga lain sangat menentukan bagi keputusan wanita memiliki balita untuk masuk ke dalam pasar kerja.

\section{UCAPAN TERIMA KASIH}

Tim peneliti, mengucapkan terimakasih atas bantuan dan dukungan kepada Pemerintah Daerah Kabupaten Agam dan Kabupaten Pasaman, Segenap Jajaran di Kecamatan dan Wali Nagari serta para surveyor dari Fakultas Ekonomi Universitas Andalas.

\section{DAFTAR PUSTAKA}

Aswiyati, Indah. (2016). Peran Wanita dalam Menunjang Perekonomian Rumah Tangga Keluarga Petani Tradisional Untuk Penanggulangan Kemiskinan di Desa Kuwil Kecamatan Kalawat. Jurnal Holistik, Tahun Ix No. 17 / Januari - Juni 2016. Pp. 1-18

Badan Pusat Statistik. (2014). - Perkembangan Beberapa Indikator Utama Sosial-Ekonomi Indonesia. Jakarta: Badan Pusat Statistik.

2015, Informasi Ketenagakerjaan Provinsi Sumatera Barat, BPS Sumbar.

Ballante, Don and Jackson Mark, (1993). "Labor Economics - Chence in Labor Markets", Mc. Graw-Hill, USA.

Becker, Garry. S. (1965). A Theory of The Allocation of Time. The Economics Journal, Vol. 75, N0. 299, pp 493-519.

Bellante, Don \& Mark Janson 2006. Ekonomi Ketenagakerjaan. Jakarta: Lembaga Penerbit Fakultas Ekonomi Universitas Indonesia.

Bashir, Saima and Muhammad Arshad Chawdhry. (2014). Does Self-employment Enhance Regional Economic Growth? Working Paper Series No. 03/2014. Department of Business and Economics California University of Pennsylvania.
Dornbush, R and Stanly Fisher. 1994. Macroeconomics. 6th edition. McGraw Hill, New York.

Coate, B., Handmer, J., and Choong, W. 2006. "Taking Care of People and Communities, Rebuilding livelihoods through NGOs and the informal econmy in Southern Thailand." Disaster Prevention and Management

Elfindri \& Nasri Bachtiar, (2004). Ekonomi Ketenagakerjaan, Andalas University Press, Padang.

Ehrenberg, Ronald G, dan Smith, Robert S, (2012). Modern Labor Economics: Theory and Public Policy, Eight Edition. Pearson Education, Inc. New York City.

Giannakopoulos, Nicholas. (2015). The Added Worker Effect of Married Women in Greece during The Great Depression, MPRA (Munich Personnal RePEct Archive Paper No. 66298.

Grant, Elisa J. Vallone and Stewart I. Donaldson. (2001). Consequences of work-family conflict on employee well-being over time, Work \& stress, 2001, 15 (3), pp. 214-226.

Guner, Nezih, Remzi Kaygusuz dan Gustavo Ventura, (2016). Child-Related Transfers, Household Labor Supply and Welfare.

Haryanto, Sugeng. (2008). Peran Aktif Wanita Dalam Peningkatan Pendapatan Rumah Tangga Miskin: Studi Kasus Pada Wanita Pemecah Batu Di Pucanganak Kecamatan Tugu Trenggalek. Jurnal Penelitian Universitas Merdeka Malang. Vol 9 No. 2 Tahun 2008

ILO, (2015). Tren Ketenagakerjaan dan Sosial di Indonesia 2014 - 2015: Memperkuat daya saing dan produktivitas melalui pekerjaan layak, Kantor Perburuhan Internasional Jakarta

Kauffman, J. M. (2003). Reflections on the field. Education and Treatment of Children, 26 (4), 325-329

Kohara, Miki. (2008). The Response of Wives' Labor Supply to Husbands' Job Loss, Journal of Population Economics, 23(4): pp. 1133-1149. 
Kurniati, Lidia, (2012). Analisis Penawaran Tenaga Kerja Wanita Menikah Sektor Informal di Kota Makassar, Fakultas Ekonomi UNHAS.

Lundberg, Shelly. (1985). "The Added Worker Effect". Journal of Labor Economics 3 (1). University of Chicago Press, Society of Labor Economists, NORC at the University of Chicago: pp. 11-37. . (1988). Labor Supply of Husbands and Wives: A Simultaneous Equations Approach. The Review of Economics and Statistics, Vol. 70, No. 2 (May, 1988), Pp. 224-235.

Mangkuprawira, S. (1985). Alokasi Waktu dan Kontribusi Kerja Anggota Keluarga dalam Kegiatan Ekonomi Rumah tangga (Studi Kasus: Di Dua Tipe Desa di Kabupaten Sukabumi, Jawa Barat). Disertasi Doktor. Sekolah Pascasarjana, Institut Pertanian Bogor, Bogor.

Marhaeni dan Manuati Dewi. (2004). Ekonomi Sumber Daya Manusia. Fakultas Ekonomi Universitas Udayana. Denpasar

Maryanti. (2000). Analisa Faktor - faktor yang Mempengaruhi TPAK Wanita di Perkotaan per Provinsi di Indonesia Tahun 2000.

Mincer, J. (1962). Labor Force Participation of Married Women. Aspects of Labor Economics A conference of the Universities - National Bureau Committee for Economic Research, 63-105.

Ngasuko, Tri Achya; (2016). Daya Saing Sumber Daya Manusia Indonesia Menghadapi Masyarakat Ekonomi ASEAN, https://www. kemenkeu.go.id

Ortega, Jorge Alejandro Vega. (2015). A Study of The Added Worker Effect in Mexico, UMEA Universtitet.

Putri, Nadia Maharani dan Evi Yulia Purwanti, (2012). Analisis Penawaran Tenaga
Kerja Wanita Menikah Dan Faktor Yang Mempengaruhinya di Kabupaten Brebes. Diponegoro Journal of Economics Volume 1, Nomor 1, Tahun 2012

Rahaju, ML Endang Edi, Tatik Mulyati \& Sumarlan. (2012). Motivasi Wanita Bekerja Dan Pengaruhnya Terhadap Kontribusi Pendapatan Keluarga (Studi Kasus di Kecamatan Taman Kota Madya Madiun), EKOMAKS Volume 1 Nomor 2 September 2012. pp. 80-94.

Simanjuntak, Payaman, J. (2001). Ekonomi Sumber Daya Manusia. Lembaga Penerbit Fakultas Ekonomi Universitas Indonesia: Jakarta.

Sukirno, Sadono (2006), Ekonomi Pembangunan, Proses, Masalah, dan Dasar Kebijakan, Edisi kedua, Kencana Prenada Media Group, Jakarta.

Sunartono, (2008), "Analisis Peningkatan Kesempatan Kerja di Indonesia”, Jurnal Sains dan Teknologi Indonesia Vol. 10 No. 1 April 2008, Hlm. 48-53.

Tarmizi, (2012), Ekonomi Ketenagakerjaan, Unsri Press, Palembang.

Todaro, Michel P. (2011), "Ekonomi Pembangunan di Dunia Ketiga" edisi Terjemahan, Erlangga.

Tarmizi, N. (2012). Ekonomi Ketenaga Kerjaan. UNSRI PRESS, Palembang.

Tukiran dkk. (2007). "Sumber Daya Manusia Tantangan Masa Depan”. Pustaka pelajar: Yogyakarta.

Wang, Fei, Liqiu Zhao \& Zhong Zhao, (2016), China's Family Planning Policies and Their Labor Market Consequences, IZA Discussion Paper No. 9746

Wirawan. (2003). Analisis Variabel - Variabel yang Mempengaruhi Tingkat Partisipasi Angkatan Kerja Wanita di Kabupaten Hulu Sungai Selatan Provinsi Kalimantan Selatan 